Vol. 15 (2006): 280-292.

\title{
Comparison of part-time grazing and indoor silage feeding on milk production
}

\author{
Auvo Sairanen \\ MTT Agrifood Research Finland, Animal Production Research, North-Savo Research Station, \\ FI-71750 Maaninka, Finland, e-mail: auvo.sairanen@mtt.fi \\ Hannele Khalili \\ MTT Agrifood Research Finland, Animal Production Research, FI-31600 Jokioinen, Finland \\ Perttu Virkajärvi \\ MTT Agrifood Research Finland, Animal Production Research, North-Savo Research Station, \\ FI-71750 Maaninka, Finland \\ Jenni Hakosalo \\ University of Kuopio, Institute of Applied Biotechnology, PO Box 1627, FI-70211 Kuopio, Finland
}

\begin{abstract}
Cows were assigned randomly to indoor silage feeding (with $2 \mathrm{~h}$ outdoor exercise) or part-time grazing treatment in two different experiments. One group was kept in confinement with ad libitum grass silage within each experiment. The other group had ad libitum grass silage indoors and they were put out on grass pasture during part of the 24 hour period, 12 hours (night, Experiment 1) and 6 hours (day, Experiment 2) in June, July and August. In Experiment 2, the concentrate $\left(9 \mathrm{~kg} \mathrm{~d}^{-1}\right)$ was given at two crude protein levels: high crude protein $\left[185 \mathrm{~g} \mathrm{~kg}^{-1}\right.$ dry matter (DM)] and low crude protein $\left(135 \mathrm{~g} \mathrm{~kg}^{-1} \mathrm{DM}\right)$. In Experiment 1 , night-time grazing increased total DM intake and milk $\left(3.9 \mathrm{~kg} \mathrm{~d}^{-1}\right)$ production. There was interaction between month and forage feeding strategy, the difference in milk yield being smallest between treatments in June. In Experiment 2, day-time grazing had no significant main effect on milk production but there was significant interaction between month and forage feeding strategy showing $2.5 \mathrm{~kg} \mathrm{~d}^{-1}$ difference between treatments in July. High-protein concentrate tended to increase the milk yield more on the silage diet compared with the group grazing during daytime. The differences in milk yield between the forage feeding treatments were mainly due to the higher dry matter intake and higher metabolizable energy content of the pasture grass compared with silage. The lower milk responses to concentrate crude protein in the cows grazing during daytime compared with the silage group indicate a high protein value of pasture grass. It is concluded that part-time grazing increases the milk yield and decreases the need for supplementary concentrate protein.
\end{abstract}

Key words: milk production, restricted grazing, dairy cows, protein supplementation 
Vol. 15 (2006): 280-292.

\section{Introduction}

Pasture is a challenging feeding strategy in Nordic latitudes because of a highly variable grass growth rate throughout the summer. The growth rate of timothy grass can be nearly $200 \mathrm{~kg}$ dry matter (DM) ha-1 per day in June, diminishing to $30 \mathrm{~kg} \mathrm{DM} \mathrm{ha}{ }^{-1}$ per day in late August (Virkajärvi 2005). This variability makes it difficult to maintain a reasonable grazing rotation system during the summer. Another factor which causes difficulties in grazing is the lack of suitable pasture land near cowsheds, especially with increasing herd sizes. These challenges together with the short, 110-day grazing season have decreased the proportion of pasture in the cow's diet during the past few decades. However, most of the Finnish dairy farms use grazing and well managed pasture is the cheapest way to feed dairy cows also at Nordic latitudes (Seppälä et al. 2006).

A closed cowshed is an environment totally different from an open pasture, and grazing affects the behaviour and welfare of cows. Cows' natural behaviour is truly possible only at pasture and therefore well managed grazing enhances animal welfare. Giving up grazing also increases milk production costs because of increasing investments in harvesting machines and forage silos.

One solution to combine economic milk production and animal welfare could be part-time grazing where diet is constituted of pasture and silage. With daytime grazing it is possible to limit the grazing time to a few hours if the pasture area is small. The most intensive grazing occurs normally in the evening (Orr et al. 2001) and the grazing time during the night is often longer than during the day due the over $12 \mathrm{~h}$ difference between evening and morning milking used commonly in Finland. Thus night-time grazing is suitable if the proportion of grazed grass should be more than half of the daily forage consumption due to lack of silage available, or hot weather conditions causes discomfort or heat stress to cows during daytime. It should be noted that nights are light in the North- ern part of Europe and grazing is possible till late autumn.

The nutritional value of grazed grass and conserved grass differs mainly as a result of the differences in growth stages of the grass at harvesting. Ensiling of herbage per se had little effect on overall animal performance (Cushnahan and Mayne 1995), but ensiling degrades the grass protein extensively and decreases the rumen microbial protein synthesis, reducing the protein value of grass silage compared with fresh grass (Verbič et al. 1999, Givens and Rulquin 2004). This leads to the requirement of different amounts of protein supplementation to pasture and silage diets. Kolver (2000) and Nielsen et al. (2003) concluded that low-yielding, pasture-fed cows need less additional concentrate protein, while Huhtanen (1998) reported no relation between milk yield and protein supplementation responses in silage-fed cows. High protein value of digestible grass could satisfy the protein requirement of late lactating cows when the total protein requirement is lower. Thus it would be possible to decrease the concentrate protein content if highquality pasture is included in the dairy cow's diet.

The aim of this study on dairy cows was to compare the effects of part time grazing $(12 \mathrm{~h}$ night-time or $6 \mathrm{~h}$ day-time) with indoor silage feeding without pasture. Another aim was to study the responses to protein supplementation between silage feeding and part-time grazing.

\section{Material and methods}

\section{Forage feeding treatments, management and pastures}

The study was conducted at the MTT North Savo Research Station, Finland, during the grazing seasons 2003 (Experiment 1) and 2005 (Experiment 2). The forage feeding treatments studied were indoor feeding with grass silage and con- 
centrate (silage feeding) or part-time grazing supplemented with silage and concentrate (nighttime grazing in 2003 and day-time grazing in 2005). The cows were housed in a tie stall where the silage feeding groups were allowed outdoor activities in the yard for two hours daily. The daily grazing time was 12 hours (1800-0600) during the night in 2003 and six hours (09001500) during the day in 2005. Both silages and pastures consisted of timothy (Phleum pratense L.) and meadow fescue (Festuca pratensis Huds.). The silages were prepared from a primary-growth sward using a formic acid-based additive $\left(5 \mathrm{t}^{-1}\right)$ and offered ad libitum (10\% refusals) in the stall. The pastures were fertilized three times during each growing season. Fertilizers were applied as three dressings (total 220 and $190 \mathrm{~kg} \mathrm{~N} \mathrm{ha}^{-1}$ year $^{-1}$ in Experiments 1 and 2, respectively), the first before the grazing season and the other two at intervals of approximately four weeks.

The cows in the pasture treatments grazed in intensive rotation with front and back fences between 27 May and 31 August in 2003 and between 30 May and 31 August in 2005. The target pasture herbage mass was $2000-3500 \mathrm{~kg}$ DM $\mathrm{ha}^{-1}$. The cows grazed as a single herd with a fixed herbage allowance (HA) of $13 \mathrm{~kg}$ DM above $3 \mathrm{~cm}$ per night in Experiment 1 . The herbage mass was measured by a method modified by Stockdale (1984) before introducing a new strip. In this method the sward height of the daily grazing area was measured by a rising plate meter (diameter $0.3 \mathrm{~m}, 3.5 \mathrm{~kg} \mathrm{~m}^{-2}$ ). Three representative sampling areas were chosen based on the previously measured mean pressed sward height of the current paddock. In each area the disk height was recorded and then a frame of 20 $\times 50 \mathrm{~cm}$ was placed on the ground, and the herbage inside the frame was cut to a height of $3 \mathrm{~cm}$. Herbage allowance was not measured in Experiment 2 , but the grazing rotation was conducted so that HA was not a limiting factor for milk production (assessed HA $>25 \mathrm{~kg} \mathrm{DM} \mathrm{d}^{-1}$ ). The cows in Experiment 2 grazed as part of a large herd staying not more than three days at the same paddoc.

\section{Experimental design and concentrate feeding}

Experiment 1 was conducted in a randomized block design using eight primiparous [104 days in milk (DIM), standard deviation (SD) 47] and 26 multiparous (108 DIM, SD 42) Holstein-Friesian cows with an average pre-experimental milk yield of $33.0 \mathrm{~kg} \mathrm{~d}^{-1}$. The cows were paired to 17 blocks according to parity, days in milk and pre-experimental milk yield, and allocated at random to forage feeding treatments. The grazing season was divided into three periods by months: June, July and August. The 7-day intake measurement period was conducted in the middle of each month. The amount of daily concentrate was fixed to at $9 \mathrm{~kg}$ $\mathrm{d}^{-1}$. Concentrates (Table 1) were given as three equal meals at 0600, 1530 and 1730. The concentrate $\left(\mathrm{g} \mathrm{kg}^{-1}\right)$ consisted of wheat bran (248), barley (234), oats (200), molassed sugar beet pulp (60), rapeseed meal (60), molassess (60), barley malt culms (50), palm kern meal (40), rapeseed cake (22) and minerals (26).

In Experiment 2, 12 primiparous (140 DIM, SD 52) and 20 multiparous cows (125 DIM, SD 69) were allocated to eight blocks according to parameters described in Experiment 1. The treatments consisted of forage feeding strategies (silage feeding and day-time grazing) and concentrate at two crude protein (CP) levels: high protein $(185 \mathrm{~g}$ $\left.\mathrm{kg}^{-1} \mathrm{DM}\right)$ and low protein $\left(130 \mathrm{~g} \mathrm{~kg}^{-1} \mathrm{DM}\right)$. The cows were randomly assigned to treatments within the blocks. The low-protein concentrate $\left(\mathrm{g} \mathrm{kg}^{-1}\right)$ consisted of rolled barley (500) and oats (500). The high-protein concentrate consisted of barley (390), oats (390) and rapeseed meal (220). The daily concentrate allowance was $9 \mathrm{~kg}$ plus $200 \mathrm{~g}$ $\mathrm{d}^{-1}$ of mineral mixture. The four dietary treatments were arranged in a $2 \times 2$ factorial cross-over design with six periods. Each month (June, July and August) was divided into two periods. Each 15-day period comprised ten days of adjustment and five days of data collection for statistical analyses. The cows remained on the same forage feeding strategy (silage feeding or day-time grazing) throughout the summer, but the protein supplementation treat- 
Vol. 15 (2006): 280-292.

Table 1. Chemical composition of experimental feeds.

\begin{tabular}{|c|c|c|c|c|c|c|c|c|}
\hline & \multicolumn{3}{|c|}{ Silage } & \multicolumn{3}{|c|}{ Grass } & \multicolumn{2}{|c|}{ Concentrate } \\
\hline & June & July & August & June & July & August & & \\
\hline \multicolumn{9}{|l|}{ Experiment 1} \\
\hline \multicolumn{9}{|l|}{ In DM, $\mathrm{g} \mathrm{kg}^{-1}$} \\
\hline Neutral detergent fibre & 567 & 604 & 609 & 435 & 513 & 512 & 293 & \\
\hline Crude protein & 179 & 152 & 154 & 256 & 228 & 203 & 167 & \\
\hline Metbolizable energy, $\mathrm{MJ} \mathrm{kg}^{-1}$ & 11.3 & 10.8 & 10.8 & 12.0 & 11.5 & 11.6 & 11.9 & \\
\hline Digestible organic matter in dry matter & 705 & 672 & 676 & 748 & 716 & 723 & & \\
\hline Amino acids absorbed from the intestine & 87 & 82 & 82 & 98 & 92 & 91 & 101 & \\
\hline Silage dry matter intake index ${ }^{\text {a }}$ & 99 & 91 & 93 & & & & & \\
\hline Sward height, $\mathrm{cm}$ & & & & 28 & 32 & 30 & & \\
\hline Herbage mass, kg DM & & & & 2350 & 2550 & 2770 & & \\
\hline Experiment 2 & & & & & & & Control $^{\mathrm{b}}$ & Suppl ${ }^{\mathrm{c}}$ \\
\hline \multicolumn{9}{|l|}{ In DM, $\mathrm{g} \mathrm{kg}^{-1}$} \\
\hline Neutral detergent fibre & 555 & 548 & 550 & 539 & 464 & 495 & 260 & 262 \\
\hline Crude protein & 148 & 179 & 167 & 199 & 231 & 211 & 130 & 185 \\
\hline Metbolizable energy, $\mathrm{MJ} \mathrm{kg}^{-1}$ & 11.0 & 10.3 & 10.5 & 11.3 & 11.4 & 11.4 & 12.5 & 12.3 \\
\hline Digestible organic matter in dry matter & 687 & 645 & 655 & 714 & 725 & 705 & & \\
\hline Amino acids absorbed from the intestine & 83 & 81 & 81 & 90 & 92 & 91 & 98.5 & 110.9 \\
\hline Silage dry matter intake index & 103 & 96 & 97 & & & & & \\
\hline
\end{tabular}

${ }^{\text {a }}$ Huhtanen et al. 2002.

${ }^{\mathrm{b}}$ Low crude protein

${ }^{c}$ High crude protein

ment was changed in three-period sequences as presented by Byron and Kenward (2003).

\section{Measurements, sample collection and analysis}

Indoor feed intake and milk production were measured daily. Milk samples from six consecutive milkings at the end of the data collection period (intake measurement period in Experiment 1) were analysed separately for fat, protein, lactose and urea content using an infrared analyzer (Milcoscan FT6000; www.foss-nirsystems.com). Live weight was measured after turnout and at the end of each period. Grass intake was estimated by the sward cutting method with two independent sets of ten plots $\left(0.1 \mathrm{~m}^{2}\right)$ per grazing strip in Experiment 1. In
Experiment 2, grass intake was calculated as a difference between energy requirement (including maintenance, milk production and live weight changes) and measured energy intake as silage plus concentrate (MTT 2006). The grass silage samples were collected weekly and stored frozen $\left(-23^{\circ} \mathrm{C}\right)$ until pooled monthly for analysis. Grass samples for chemical analysis were collected once a week before the start of grazing. The collected grass samples were stored frozen and then ovendried at $60^{\circ} \mathrm{C}$ for analyses.

The DM content of the grass was determined by drying the samples at $105^{\circ} \mathrm{C}$ for $20 \mathrm{~h}$. The nitrogen content of the dried samples was determined by a Dumas type $\mathrm{N}$ analyzer (Leco Fp-428), N content of silage (Kjeldahl-N) by the AOAC (1990) method, neutral detergent fibre (NDF) according to Van Soest et al. (1991, sodium sulfite was used in NDF-detergent solution) and in vitro OM di- 
gestibility by a modification of the method described by Nousiainen et al. (2003). In this method the results were calculated with a correction equation to convert the OM pepsin-cellulase solubility into in vivo digestibility by an equation based on a data set comprising Finnish in vivo digestibility trials. Silage $\mathrm{pH}$, volatile fatty acids and ammonium $\mathrm{N}$ were analyzed by the titration method (Moisio and Heikonen 1989). The silage dry matter intake index (SDMI) was calculated based on silage fermentation quality and $\mathrm{D}$ value ( $\mathrm{g}$ digestible $\mathrm{OM}$ $\mathrm{kg}^{-1} \mathrm{DM}$ ) according to Huhtanen et al. (2002). Silage and grass amino acids absorbed from the intestine (AAT, Madsen et al. 1995) were calculated based on grass and silage CP and D values (MTT 2004). The metabolizable energy (ME) content for grass and silage was calculated by assessing the energy content of $0.016 \mathrm{MJ} \mathrm{g}^{-1}$ digestible OM. The $\mathrm{ME}$ and AAT contents of the concentrate were assessed as described by MTT (2006).

\section{Statistical analysis}

\section{Experiment 1}

Differences between treatment means in milk production, estimated feed consumption and live weight were tested for significance using the analysis of variance for repeated measurements (SAS Mixed, Co-variance structure AR1) according to the following equation:

$$
\begin{aligned}
\mathrm{y}_{\mathrm{ijk}}= & \mu+\text { block }_{\mathrm{i}}+\text { forage }_{\mathrm{j}}+\text { month }_{\mathrm{k}}+\text { forage }_{\mathrm{j}} \times \\
& \text { month }_{\mathrm{k}}+\text { error }_{\mathrm{ijk}}
\end{aligned}
$$

where forage is the effect of forage feeding strategy; silage feeding or part-time grazing.

\section{Experiment 2}

The effect of forage feeding strategy on milk production, calculated feed consumption and live weight was analysed with the repeated measurement model (SAS Mixed, Co-variance structure AR1) using the following equation:

$$
\begin{aligned}
\mathrm{y}_{\mathrm{ijk}}= & \mu+\text { block }_{\mathrm{i}}+\text { forage }_{\mathrm{j}}+\text { month }_{\mathrm{k}}+\text { forage }_{\mathrm{j}} \times \\
& \text { month }_{\mathrm{k}}+\text { error }_{\mathrm{ijk}}
\end{aligned}
$$

The effect of protein supplementation on milk production was analysed according to the following equation for cross over design:

$$
\begin{aligned}
\mathrm{y}_{\mathrm{ijkl}}= & \mu+\text { block }_{\mathrm{i}}+\text { forage }_{\mathrm{j}}+\text { supplementation }_{\mathrm{k}}+ \\
& \text { period }_{1}+\text { forage }_{\mathrm{j}} \times \text { supplementation }_{\mathrm{k}}+ \\
& \text { period }_{1} \times \text { forage }_{\mathrm{j}}+\text { error }_{\mathrm{ijkl}}
\end{aligned}
$$

where supplementation is the effect of concentrate $\mathrm{CP}$ content. Cow was included in the model as a random factor.

\section{Results}

Total average precipitation per month for Experiments 1 and 2 was 73 and $77 \mathrm{~mm}$, respectively. Respective average temperatures during the grazing time were $13.7^{\circ} \mathrm{C}$ in Experiment 1 and $19.1^{\circ} \mathrm{C}$ in Experiment 2. The warmest period (average temperature during grazing $25.6^{\circ} \mathrm{C}$, mean relative humidity $47.0 \%$ ) started on 9 July and ended on 16 July in Experiment 2.

The chemical composition of feeds is presented in Table 1 . The fermentation quality of the grass silage was good all over in terms of $\mathrm{pH}$ (3.9, SD $0.12)$, volatile fatty acids (11.7 $\left.\mathrm{g} \mathrm{kg}^{-1} \mathrm{DM}\right), \mathrm{SD}$ 3.66), lactic plus formic acid (58 $\left.\mathrm{g} \mathrm{kg}^{-1} \mathrm{DM}\right), \mathrm{SD}$ 14) and proportion of ammonia in the total nitrogen (39 $\mathrm{g} \mathrm{kg}^{-1}$ total $\left.\left.\mathrm{N}\right), \mathrm{SD} 1.1\right)$. The ME and AAT contents of silage and DM intake index of silage were higher in June than in July and August in both experiments (Table 1). The differences in nutritive value of silages were consequence of differences in harvesting day. The growth stage of the grass silage was advanced compared to pasture, which can be seen in the low contents of silage ME, AAT and CP in silages, while the NDF content of silage was high compared with that of grass.

\section{Experiment I}

Night-time grazed cows had small amounts of concentrate refusals in June, for the rest of the time 
Vol. 15 (2006): 280-292.

they consumed all the concentrates given. Grazing increased numerically the total measured DM and ME intake in Experiment 1 (Table 2), showing an average $0.74 \mathrm{~kg} \mathrm{~kg}^{-1}$ substitution rate for silage when pasture was included in the diet. The total DM and ME intake was not statistically tested due to absence of individual grass intake measurements within each period. The DM intake decreased during the summer on silage feeding strategy, while the highest DM intake was measured in August in the night-time grazing group. The proportion of grazed grass averaged 34\% of total DM intake and $55 \%$ of total consumed forage.

Grazing increased milk and energy-corrected milk (ECM) yields $(\mathrm{P}<0.001$, Table 3, Figure 1a). The differences were smaller in June compared with July and August (interaction between month and forage feeding strategy $\mathrm{P}<0.05)$. The average milk yield was $3.9 \mathrm{~kg} \mathrm{~d}^{-1}(3.1 \mathrm{~kg}$ ECM) higher on night-time grazing than on silage feeding group. Grazing decreased milk fat content significantly (P $<0.01)$ and tended to increase $(\mathrm{P}<0.1)$ milk protein content. The forage feeding strategy had no major effect on live weight, but apparent live weight gain was greater $(\mathrm{P}<0.05)$ on the nighttime grazing treatment $\left(0.45 \mathrm{~kg} \mathrm{~d}^{-1}\right)$ than on the silage feeding treatment $\left(0.20 \mathrm{~kg} \mathrm{~d}^{-1}\right)$.

\section{Experiment 2}

Grazing decreased silage intake $(\mathrm{P}<0.001)$, but forage feeding strategy had no effect on total DM or ME intake when pasture grass intake was calculated on the basis of the cow's energy requirement (Table 2). The proportion of pasture DM was $22 \%$ of the total DM consumed.

Table 2. Effect of forage type on feed intake during the summer.

\begin{tabular}{|c|c|c|c|c|c|c|c|c|c|}
\hline & \multicolumn{2}{|c|}{ June } & \multicolumn{2}{|c|}{ July } & \multicolumn{2}{|c|}{ August } & \multirow[b]{2}{*}{ SEM } & \multicolumn{2}{|c|}{ Significance } \\
\hline & Silage & Pasture & Silage & Pasture & Silage & Pasture & & Diet & Diet $\times$ Month \\
\hline \multicolumn{10}{|l|}{ Experiment 1} \\
\hline \multicolumn{10}{|l|}{ Feed intake, $\mathrm{kg} \mathrm{DM} \mathrm{d}^{-1}$} \\
\hline Silage & 11.5 & 5.3 & 10.3 & 4.7 & 9.8 & 6.5 & 0.32 & $<0.001$ & $<0.001$ \\
\hline Grazed grass & & 6.7 & & 6.9 & & 6.7 & $-{ }^{a}$ & - & - \\
\hline Total forage & 11.5 & 12.0 & 10.3 & 11.6 & 9.8 & 13.2 & - & - & - \\
\hline Concentrate & 7.8 & 7.7 & 7.8 & 7.8 & 7.8 & 7.8 & - & - & - \\
\hline Total & 19.3 & 19.9 & 18.1 & 19.4 & 17.6 & 21.0 & - & - & - \\
\hline Metabolizable energy intake, $\mathrm{MJ} \mathrm{d}^{-1}$ & 221 & 234 & 203 & 222 & 198 & 240 & - & - & - \\
\hline \multicolumn{10}{|l|}{ Experiment 2} \\
\hline \multicolumn{10}{|l|}{ Feed intake, $\mathrm{kg} \mathrm{DM} \mathrm{d}^{-1}$} \\
\hline Silage & 11.1 & 7.5 & 11.5 & 6.9 & 10.6 & 6.7 & 0.38 & $<0.001$ & $<0.001$ \\
\hline Grass $^{b}$ & & 4.0 & & 4.9 & & 3.7 & - & - & - \\
\hline Total forage & 11.1 & 11.5 & 11.5 & 11.8 & 10.6 & 10.4 & - & - & - \\
\hline Concentrate & 7.6 & 7.6 & 7.4 & 7.2 & 7.6 & 7.7 & - & - & - \\
\hline Total & 18.8 & 19.2 & 18.9 & 19.0 & 18.2 & 18.2 & - & - & - \\
\hline Metabolizable energy intake. $\mathrm{MJ} \mathrm{d}^{-1}$ & 217 & 223 & 211 & 218 & 204 & 208 & - & - & - \\
\hline
\end{tabular}

Silage $=$ indoor silage feeding + outdoor exercise $2 \mathrm{~h}$.

Pasture $=$ indoor silage feeding + night-time grazing $(12 \mathrm{~h})$ in Experiment 1 and indoor silage feeding + day-time grazing (6 h) in Experiment 2.

${ }^{a}$ Grass intake has not been tested statistically due to lack of independent replicates.

${ }^{\mathrm{b}}$ Grass intake was calculated as the difference between energy requirement and dry matter intake indoors (MTT 2006). 
Sairanen, A. et al. Comparison of part-time grazing and indoor silage feeding

Table 3. Effect of forage type on animal performance during the summer.

\begin{tabular}{|c|c|c|c|c|c|c|c|c|c|c|}
\hline & \multicolumn{2}{|c|}{ June } & \multicolumn{2}{|c|}{ July } & \multicolumn{2}{|c|}{ August } & \multicolumn{4}{|c|}{ Significance } \\
\hline & Silage & Pasture & Silage & Pasture & Silage & Pasture & SEM $^{\mathrm{a}}$ & Diet & SEM $^{\mathrm{b}}$ & $\begin{array}{l}\text { Diet } \times \\
\text { Month }\end{array}$ \\
\hline \multicolumn{11}{|l|}{ Experiment 1} \\
\hline Live weight, $\mathrm{kg}$ & 588 & 586 & 599 & 601 & 600 & 613 & 8.7 & NS & 8.9 & $<0.01$ \\
\hline Milk, $\mathrm{kg} \mathrm{d}^{-1}$ & 31.3 & 34.2 & 26.8 & 31.2 & 24.5 & 28.9 & 0.50 & $<0.001$ & 0.55 & $<0.001$ \\
\hline Energy corrected milk, $\mathrm{kg} \mathrm{d}^{-1}$ & 31.3 & 33.5 & 26.8 & 30.0 & 25.0 & 29.0 & 0.49 & $<0.001$ & 0.56 & $<0.001$ \\
\hline \multicolumn{11}{|l|}{ Milk composition, $\mathrm{g} \mathrm{kg}^{-1}$} \\
\hline Fat & 40.0 & 37.8 & 40.6 & 37.0 & 41.6 & 39.8 & 0.52 & $<0.01$ & 0.62 & $<0.1$ \\
\hline Protein & 31.3 & 32.4 & 31.2 & 32.5 & 32.5 & 33.6 & 0.35 & $<0.1$ & 0.39 & NS \\
\hline Urea, $\mathrm{mg} \mathrm{dl}^{-1}$ & 38.8 & 35.2 & 35.0 & 39.2 & 30.9 & 32.1 & 0.48 & NS & 0.56 & $<0.001$ \\
\hline \multicolumn{11}{|l|}{ Milk component yield, $\mathrm{g} \mathrm{d}^{-1}$} \\
\hline Fat & 1249 & 1292 & 1083 & 1153 & 1012 & 1147 & 17.9 & $<0.01$ & 22.8 & $<0.05$ \\
\hline Protein & 976 & 1102 & 833 & 994 & 794 & 968 & 17.3 & $<0.001$ & 19.4 & $<0.05$ \\
\hline \multicolumn{11}{|l|}{ Experiment 2} \\
\hline Live weight, $\mathrm{kg}$ & 598 & 592 & 607 & 585 & 616 & 610 & 8.5 & NS & 8.9 & $<0.01$ \\
\hline Milk, $\mathrm{kg} \mathrm{d}^{-1}$ & 29.3 & 29.7 & 26.5 & 29.0 & 25.2 & 26.8 & 0.68 & 0.12 & 0.73 & $<0.01$ \\
\hline Energy corrected milk, $\mathrm{kg} \mathrm{d}^{-1}$ & 28.9 & 28.8 & 26.2 & 28.0 & 25.2 & 25.7 & 0.49 & NS & 0.56 & $<0.01$ \\
\hline \multicolumn{11}{|l|}{ Milk composition, $\mathrm{g} \mathrm{kg}^{-1}$} \\
\hline Fat & 40.9 & 38.8 & 40.9 & 39.1 & 41.4 & 38.3 & 1.02 & 0.10 & 1.10 & NS \\
\hline Protein & 32.6 & 32.5 & 33.2 & 33.1 & 34.3 & 34.2 & 0.49 & NS & 0.51 & NS \\
\hline Urea, $\mathrm{mg} \mathrm{dl}^{-1}$ & 24.4 & 25.4 & 36.5 & 37.1 & 35.6 & 36.0 & 1.09 & NS & 1.20 & NS \\
\hline \multicolumn{11}{|l|}{ Milk component yield, $\mathrm{g} \mathrm{d}^{-1}$} \\
\hline Fat & 1189 & 1148 & 1078 & 1124 & 1036 & 1008 & 25.5 & NS & 29.0 & $<0.01$ \\
\hline Protein & 947 & 957 & 876 & 948 & 860 & 907 & 13.2 & $<0.05$ & 15.8 & $<0.01$ \\
\hline
\end{tabular}

Silage $=$ indoor silage feeding + outdoor exercise $2 \mathrm{~h}$.

Pasture $=$ indoor silage feeding + night-time grazing $(12 \mathrm{~h})$ in Experiment 1 and indoor silage feeding + day-time grazing (6 h) in Experiment 2.

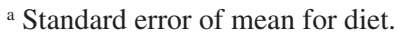

${ }^{\mathrm{b}}$ Standard error of mean for diet $\times$ month interaction; month $=$ June, July and August.

Grazing tended to increase the average milk yield $(\mathrm{P}=0.12)$ by $1.5 \mathrm{~kg}(0.7 \mathrm{~kg} \mathrm{ECM})$ in Experiment 2 (Table 3, Figure 1b). There was interaction between month and forage feeding strategy in milk yield $(\mathrm{P}<0.001)$, with the greatest difference in July ( $2.5 \mathrm{~kg}$ milk) and the smallest in June (0.4 $\mathrm{kg}$ milk). Grazing tended to decrease milk fat content $(\mathrm{P}=0.10)$, but had no effect on milk protein content.

Rapeseed meal supplementation increased milk $(\mathrm{P}<0.001)$ and ECM $(\mathrm{P}<0.001)$ yields as well as milk protein $(\mathrm{P}<0.001)$ and urea contents $(\mathrm{P}<0.001)$, while milk fat content tended to decrease $(\mathrm{P}=0.11$, Table 4$)$. Milk yield response to supplementation tended to be greater $(\mathrm{P}<0.07)$ on the silage feeding group $(0.9 \mathrm{~kg}$ milk kg-1 rapeseed meal) compared with the day-time grazing group (0.6 kg milk kg-1 rapeseed meal) when rapeseed meal substituted for grain. Rapeseed meal supplementation increased milk protein yield $(\mathrm{P}<0.01)$ more on silage feeding group $\left(81 \mathrm{~g} \mathrm{~d}^{-1}\right)$ compared with day-time grazed group $\left(45 \mathrm{~g} \mathrm{~d}^{-1}\right)$. 
Vol. 15 (2006): 280-292.

a) Milk production,

a) $\mathrm{kg}$ cow-1 day-1

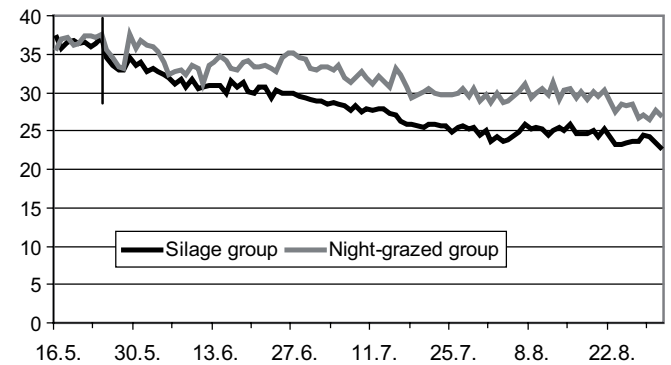

Milk production,

b) $\mathrm{kg} \mathrm{cow}-1$ day-1

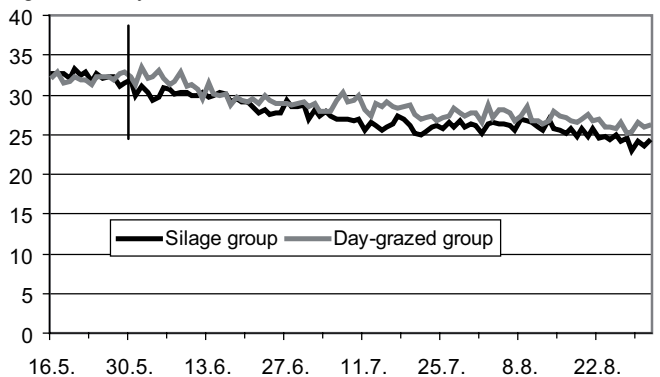

Fig. 1. Milk production a) during the summer 2003 and b) during the summer 2005. Vertical lines presents cows' turnout to pasture.

\section{Discussion}

\section{Milk yield}

Numerically part-time grazing produced more milk compared with the silage feeding in both experiments (Figs. 1a, b). The increment in milk yield was $0.33 \mathrm{~kg}$ milk per hour of grazing time for night-time grazing and $0.25 \mathrm{~kg}$ milk $\mathrm{h}^{-1}$ for daytime grazing. This agrees with the results reported by Dillon et al. (2002) where part-time grazing increased the milk yield by $0.31 \mathrm{~kg} \mathrm{~h}^{-1}$ of increased grazing time. One reason for the low grazing response late in June in Experiment 2 (Fig. 1b) was the difficulties in maintaining pasture rotation due to weather conditions resulting mature growth stage of grass. The rigid grass stem lowered both the utilization and energy content of pasture grass (D value $670 \mathrm{~g} \mathrm{~kg}^{-1} \mathrm{DM}$ ), which decreased the production value of pasture for three weeks. Pasture rotation was corrected by topping and the amount and the quality of the pasture improved at the beginning of July (D value $>710 \mathrm{~g} \mathrm{~kg}^{-1} \mathrm{DM}$ ), which can be seen also in the milk production. The cows

Table 4. Effect of protein supplementation on milk production in Experiment 2.

\begin{tabular}{|c|c|c|c|c|c|c|c|}
\hline & \multicolumn{2}{|c|}{ Silage } & \multicolumn{2}{|c|}{ Pasture } & \multirow[b]{2}{*}{ SEM } & \multicolumn{2}{|c|}{ Significance } \\
\hline & Low $\mathrm{CP}^{\mathrm{a}}$ & High CP & Low CP & High CP & & $\mathrm{CP}$ & $\mathrm{CP} \times$ forage $^{\mathrm{b}}$ \\
\hline Milk, $\mathrm{kg} \mathrm{d}^{-1}$ & 26.0 & 28.0 & 27.9 & 29.1 & 0.71 & $<0.001$ & 0.07 \\
\hline Energy corrected milk, $\mathrm{kg} \mathrm{d}^{-1}$ & 25.8 & 27.6 & 26.9 & 28.2 & 0.52 & $<0.001$ & 0.14 \\
\hline \multicolumn{8}{|l|}{ Milk composition, $\mathrm{g} \mathrm{kg}^{-1}$} \\
\hline Fat & 41.3 & 40.7 & 38.7 & 38.7 & 1.05 & 0.11 & NS \\
\hline Protein & 33.1 & 33.7 & 33.2 & 33.4 & 0.49 & $<0.001$ & 0.08 \\
\hline Urea, $\mathrm{mg} \mathrm{dl}^{-1}$ & 28.7 & 35.6 & 29.3 & 37.2 & 1.13 & $<0.001$ & NS \\
\hline \multicolumn{8}{|l|}{ Milk component yield, $\mathrm{g} \mathrm{d}^{-1}$} \\
\hline Fat & 1065 & 1131 & 1071 & 1119 & 26.7 & $<0.001$ & NS \\
\hline Protein & 853 & 934 & 916 & 961 & 14.1 & $<0.001$ & $<0.01$ \\
\hline
\end{tabular}

Silage $=$ indoor silage feeding + outdoor exercise $2 \mathrm{~h}$.

Pasture $=$ indoor silage feeding + day-time grazing $6 \mathrm{~h}$.

${ }^{\text {a }} \mathrm{CP}=$ crude protein content in concentrate.

${ }^{\mathrm{b}}$ Forage $=$ forage feeding treatment: indoor silage feeding or day-time grazing $(6 \mathrm{~h})$. 
in the day-time grazed group lost live weight from June to July, whereas the silage group gained weight more steadily throughout the summer. This suggests more negative energy balance for pasture group compared to silage group during the low pasture quality period.

The decline of the lactation curve was substantial in the silage group $\left(141 \mathrm{~g} \mathrm{~d}^{-1}\right)$ compared with the group grazed during night-time $\left(81 \mathrm{~g} \mathrm{~d}^{-1}\right)$ between 24 May 2003 and 1 August 2003 (Fig. 1a). According to the Finnish milk recording scheme, the expected decrease in daily milk yield should be $73 \mathrm{~g} \mathrm{~d}^{-1}$ at the lactation stage of the cows in the current study. Thus the recorded average difference of $3.9 \mathrm{~kg}$ in milk yield between the silage group and the group grazing during night-time was due to the exceptionally high decline in milk yield in the silage feeding group in June and July. The amount of concentrate used was quite low in Experiment 1 , taking into account the energy content of silage especially in July and August (Huhtanen 1998, Rinne 2000). As predicted by the SDMI value of the silage in July, the cows in the silagefed group were not capable of compensating the lower silage quality by increased total DM intake in the middle of the Experiment 1. Silage was substituted for high ME energy content pasture by night-time grazing and the silage quality limited the milk production of the pasture group less compared with the silage group.

\section{Heath stress and animal welfare}

In Experiment 2, during a hot period the cows exhibited symptoms of heat stress, panting and sweating (Kadzere et al. 2002) and they lied down in the cool stall when they went into the cowshed for milking. High daytime temperatures did not decrease the respective milk yields (Fig. 1b). Conversely, the average milk yield of cows grazed during day-time increased due to the better quality of pasture at that time. Thus the short period of heat stress did not disturb milk production despite the discomfort to the cows.

Heat stress is one part of animal welfare. Preliminary results of the other welfare parameters measured in Experiment 1 have been reported earlier by Virkajärvi et al. 2004. These parameters included locomotion score, hoof and muscle conditions, stereotypic behaviour, serum base cortisol and serum ACTH cortisol. The results showed quite small differences in welfare between the silage group and night-time grazing. One explanation to this would be that cows in the silage group were allowed to outdoor exercise for 2 hours. The activity of the cows on the exercise yard was quite low but it would be possible that outdoor activities have brought benefit for the stall housed cows.

\section{Energy intake}

The calculated energy content of the consumed forage was $0.5 \mathrm{MJ} \mathrm{ME} \mathrm{kg}^{-1} \mathrm{DM}$ lower on silage fed cows compared with night-time grazing group. According to Rinne 2000, an increase of $1 \mathrm{MJ}$ ME $\mathrm{kg}^{-1} \mathrm{DM}$ in silage energy content produces $1.69 \mathrm{~kg}$ extra milk. Thus the increased forage energy content could explain $0.8 \mathrm{~kg}$ of the observed $3.9 \mathrm{~kg}$ difference in milk production between silage feeding and night-time grazing groups. Increased dietary ME content together with increased total intake resulted in an increment of $25 \mathrm{MJ}$ ME in energy intake in the group grazing during night-time. According to Huhtanen (1998), the increased grass intake is highly efficient in milk production $(0.14$ $0.17 \mathrm{~kg}$ milk $\mathrm{MJ}^{-1}$ additional ME), which could explain all the difference in milk yield between silage feeding and night-time grazed group if the change in live weight gain is not taken into account. The average apparent live weight gain was $0.45 \mathrm{~kg} \mathrm{~d}^{-1}$ on night-time grazed group, which reserves $15 \mathrm{MJ} \mathrm{d}^{-1}$ (MTT 2006). The true live weight gain is possibly smaller than the measured weight, because a significant part of the weight gain could be due to increased rumen fill throughout the summer (Virkajärvi et al. 2002). However, the greater live weight gain of night-time grazed cows suggests better energy balance of pasture fed cows compared to indoor fed cows.

One reason for the increased dry matter intake in the group grazing during night-time compared 
Vol. 15 (2006): 280-292.

with the silage group could be the good palatability of fresh grass. The sugars in the grass are mostly fermented into organic acids in the silo which in large amounts reduce the silage intake (Huhtanen et al. 2002), while fresh grass is free from fermentation. The sugar content of the grass is high in the evening, which also increases the palatability of the grass and, consequently, the nutritive value of the night-time pasture compared with day-time pasture (Orr et al. 2001). However, according to Cushnahan and Mayne (1995), the effect of grass ensiling on milk production is small, at least in the case of restricted fermented silage. Another possible reason for the high intake of pasture diets is the high NDF degradation rate at the early growth stage of grass, which reduces rumen fill limitations and makes it possible to increase the dry matter intake (Kolver et al. 1998, Rinne et al. 2002, Sairanen et al. 2005).

\section{Protein supplementation}

Milk responses to protein supply tended to be higher in the silage group $\left(0.9 \mathrm{~kg} \mathrm{ECM} \mathrm{kg}^{-1}\right.$ rapeseed meal) compared with the group grazing during day-time $\left(0.65 \mathrm{~kg} \mathrm{~kg}^{-1}\right)$ in Experiment 2 (Table 4 ), which supports the assumption of high protein value of pasture. The response of milk protein yield to increased AAT was also smaller in the group grazing during day-time $\left(0.31 \mathrm{~g} \mathrm{~g}^{-1}\right.$ AAT $)$ compared with the silage group $\left(0.50 \mathrm{~g} \mathrm{~g}^{-1}\right.$ AAT $)$ where the response of the silage group was close to $0.55 \mathrm{~g} \mathrm{~g}^{-1}$ AAT according to silage studies reported by Huhtanen (1998). The microbial synthesis in the rumen increases with increasing grass digestibility (Rinne et al. 1999) and, consequently, the protein value of pasture is higher compared with silage harvested in a more mature growth stage (MTT 2006). The ensiling process ferments watersoluble carbohydrates into organic acids which are not a good energy source for microbial ATP (adenosine triphosphate) production, decreasing microbial synthesis. However, despite the lowered response to protein supplement in milk protein production on day-time pasture diet, the calculated AAT balance was $-98 \mathrm{~g} \mathrm{~d}^{-1}$ on low crude protein pasture diet, which indicates an underestimation of the AAT value and/or intake of pasture.

The proportion of pasture in the day-time grazed diet was $22 \%$ of DM and therefore the differences in the responses of milk yield to protein supplement between silage feeding and day-time grazing treatments were not numerically remarkable. The responses to protein supplementation in the present study are in line with the results of the pasture study observed in the earlier experiment with the same herd at MTT Maaninka (Sairanen 2006, unpublished results). In that experiment there was only a small difference in the ECM production between low-protein (CP $140 \mathrm{~g} \mathrm{~kg}^{-1} \mathrm{DM}$ ) and high-protein (CP $\left.180 \mathrm{~g} \mathrm{~kg}^{-1} \mathrm{DM}\right)$ diets (28.1 vs. $28.4 \mathrm{~kg} \mathrm{ECM} \mathrm{d}^{-1}$, respectively, $\mathrm{P}=0.23$ ). The reported responses to protein supplementation of pasture-fed cows vary, but they are generally fairly low (Tesfa et al. 1995, Wales et al. 2000, McCormick et al. 2001). It has been concluded that energy is a more limiting factor in milk production than protein on high-quality pasture below a milk production level of $30 \mathrm{~kg}$ (Wales et al. 1999, Kolver 2000, Bargo et al. 2003). According to this it is possible to decrease the concentrate protein content when pasture is included in the cow's diet.

An unnecessarily high protein content in the concentrate is both uneconomic and environmentally harmful. The increased milk urea content on high $\mathrm{CP}$ diets in Experiment 2 suggests decreased dietary $\mathrm{N}$ efficiency and increased urinary $\mathrm{N}$ excretion (Nousiainen et al. 2004). Urinary N is more vulnerable to leaching compared with manure $\mathrm{N}$ (Whitehead 2000). High dietary $\mathrm{N}$ increases urea production also in the liver and this causes some loss of metabolic energy. It is notable that the milk protein yield was almost the same on both high CP concentrate silage diet and low CP day-time grazing diet. High protein yield combined with low milk urea content indicates improved efficiency of dietary $\mathrm{N}$.

\section{Land use}

Part-time grazing decreases the requirement of pasture area and makes it possible to choose be- 
tween different grazing strategies according to the specific conditions on individual farms. The calculated average pasture area during the typical $110 \mathrm{~d}$ grazing season would have averaged 0.18 ha per cow in Experiment 1 and 0.11 ha per cow in Experiment 2. This estimation is based on measured intake of experimental cows in this study and an average weekly herbage growth rate of timothy pastures (variation 180 to $30 \mathrm{~kg} \mathrm{DM} \mathrm{ha}^{-1} \mathrm{~d}^{-1}$ ) during the summer. The growth rate has been measured at the MTT North Savo Research Station in 1999-2004 (Virkajärvi 2005).

The average pasture area on full-time grazing should have been 0.26 ha $^{-1}$ at the concentrate feeding level of this study. The land area needed for full-time grazing would be even higher in practice due to difficulties in grass growth utilization in the variable weather conditions. A cow's energy requirement remains quite stable throughout the season and therefore decreased herbage growth must be compensated; the grazing area has to be doubled from June to August because of decreasing herbage growth rates in Nordic conditions.

\section{Conclusions}

The total feed intake and milk production increased by allowing the cows to graze part of the day instead of feeding them totally indoors. The allocated grazing time and subsequently the proportion of pasture were greater in cows grazing during nighttime compared with day-time grazing. This resulted greater differences in milk production between the compared treatments within night-time grazing than within day-time grazing. The increased dry matter intake explained the most of the differences in milk yield between the treatments. The metabolizable energy content of forages explained differences in milk yield during the summer within each experiment. Lower responses of milk to concentrate crude protein in day-time grazing cows compared with the silage group indicated a high protein value of pasture grass, which was the other reason for the greater milk yield of pasture-fed cows compared with the silage group. According to these results, the concentrate protein supplementation could be reduced by part-time grazing compared to silage feeding with silage.

\section{References}

AOAC 1990. Official methods of analysis. 15th edition. Associations of Official Analytical Chemists.

Bargo, F., Muller, L., Kolver, E. \& Delahoy, J. 2003. Invited review: Production and digestion of supplemented dairy cows on pasture. Journal of Dairy Science 86: $1-42$.

Byron, J. \& Kenward M. 2003. Design and analysis of crossover trials. Boca Raton, FL: Chapman \& Hall/CRC. $382 \mathrm{p}$.

Cushnahan, A. \& Mayne, C.S. 1995. Effects of ensilage of grass on performance and nutrient utilization by dairy cattle 1. Food intake and milk production. Animal Science 60: 337-345.

Dillon, P., Crosse, S., O'Brien, B. \& Mayes, R. 2002. The effect of forage type and level of concentrate supplementation on the performance of spring calving dairy cows in early lactation. Grass and Forage Science 57: 212-223.

Givens, D. \& Rulquin, H. 2004. Utilisation by ruminants of nitrogen compounds in silage-based diets. Animal Feed Science and Technology 114: 1-18.

Huhtanen, P. 1998. Supply of nutrients and productive responses in dairy cows given diets based on restrictively fermented silage. Agricultural and Food Science in Finland 7: 219-250.

Huhtanen, P., Khalili, H., Nousiainen, J.I., Rinne, M., Jaakkola, S., Heikkilä, T. \& Nousiainen, J. 2002. Prediction of the relative intake potential of grass silage by dairy cows. Livestock Production Science 73: 111-130.

Kadzere, C., Murphy, M., Silanikove, N. \& Maltz, E. 2002. Heat stress in lactating dairy cows: a review. Livestock Production Science 77: 59-91.

Kolver, E. 2000. Nutrition guidelines for the high producing dairy cow. Proceedings of the Ruakura Dairy Farmers' Conference 52: 17-28. Available on the Internet: http:// www.dexcel.co.nz/data/usr/kolver.pdf.

Kolver, E., Muller, D., Barry, C. \& Penno, J. 1998. Evaluation and application of the Cornell net carbohydrate and protein system for dairy cows fed diets based on pasture. Journal of Dairy Science 81: 2029-2039.

McCormick, M., Ward, J., Redfearn, D., French, D., Blouin, D., Chapa, A. \& Fernandez, J. 2001. Supplemental dietary protein for grazing dairy cows: Effect on pasture intake and lactation performance. Journal of Dairy Science 84: 896-907.

Madsen, J., Hvelplund, T., Weisbjerg, M.R., Bertilson, J., Ohlsson, J., Spörndly, R., Harstadt, O.M., Volden, H., Tuori, M., Varvikko, T., Huhtanen, P. \& Olafson, B.L. 1995. The AAT/PBV protein evaluation systems for ru- 
Vol. 15 (2006): 280-292.

minants. A revision. Norwegian Journal of Agricultural Science 19(Suppl.): 1-37.

Moisio, T. \& Heikonen, M. 1989. A titration method for silage assessment. Animal Feed Science and Technology 22: 341-353.

MTT 2006. Rehutaulukot ja ruokintasuositukset (Feed tables and feeding recommendations). Jokioinen: MTT Agrifood Research Finland. Updated 14 February 2006. Cited 15 October 2006. Available on the Internet: http://www.agronet.fi/rehutaulukot/. URN:NBN:fife20041449.

Nielsen, N., Kristensen, T., Nørgaard, P. \& Hansen, H. 2003. The effect of low protein supplementation to dairy cows grazing clover grass during half of the day. Livestock Production Science 81: 293-306.

Nousiainen, J., Rinne, M., Hellämäki, M. \& Huhtanen, P. 2003. Prediction of the digestibility of the primary growth of grass silages harvested at different stages of maturity from chemical composition and pepsin-cellulase solubility. Animal Feed Science and Technology 103: 97-111.

Nousiainen, J., Shingfield, K.J. \& Huhtanen, P. 2004. Evaluation of milk urea nitrogen as a diagnostic of protein feeding. Journal of Dairy Science 87: 386-398.

Orr, R.J., Rutter, S.M., Penning, P.D. \& Rook, A.J. 2001. Matching grass supply to grazing patterns for dairy cows. Grass and Forage Science 56: 352-361.

Rinne, M. 2000. Influence of timing of the harvest of primary grass growth on herbage quality and subsequent digestion and performance in the ruminant animal. Ph.D. Thesis. University of Helsinki. Finland. 42 p.

Rinne, M., Jaakkola, S., Kaustell, K., Heikkilä, T. \& Huhtanen, P. 1999. Silages harvested at different stages of grass growth vs. concentrate foods as energy and protein sources in milk production. Animal Science 69: 251-263.

Rinne, M., Huhtanen, P. \& Jaakkola, S. 2002. Digestive processes of dairy cows fed silages harvested at four stages of grass maturity. Journal of Animal Science 80: 1986-1998.

Sairanen, A., Khalili, H., Nousiainen, J.I., Ahvenjärvi, S. \& Huhtanen, P. 2005. The effect of concentrate supplementation on nutrient flow to the omasum in dairy cows receiving freshly cut grass. Journal of Dairy Science 88: 1443-1453.

Seppälä, R., Sipiläinen, T., Ryhänen, M., Sairanen, A., Virkajärvi, P., Palva, R. \& Rinne, M. 2006. Laidun lypsylehmien ruokinnassa - pitkän aikavälin taloustarkastelu. In: Laajentavien karjojen kesäruokintavaihtoehdot, lisalmi 19.4.2006. Suomen nurmiyhdistyksen julkaisu nro 23. p. 18-45.
Stockdale, C.R. 1984. Evaluation of techniques for estimating the yield of irrigated pastures intensively grazed by dairy cow. 2. The rising plate meter. Australian Journal of Experimental Agriculture 24: 305-311.

Tesfa, A., Virkajärvi, P., Tuori, M. \& Syrjälä-Qvist, L. 1995. Effects of supplementary concentrate composition on milk yield, milk composition and pasture utilization of rotationally grazed dairy cows. Animal Feed Science and Technology 56: 143-154.

Wales, W., Dellow, D. \& Doyle, P. 1999. Degradabilities of dry matter and crude protein from perennial herbage and supplements used in dairy production systems in Victoria. Australian Journal of Experimental Agriculture 39: 645-656.

Wales, W., Dellow, D. \& Doyle, P. 2000. Protein supplementation of cows grazing limited amounts of paspalum (Paspalum dilatatum Poir.)-dominant irrigated pasture in mid lactation. Australian Journal of Experimental Agriculture 40: 923-929.

Van Soest, P., Robertson, J. \& Lewis, B. 1991. Methods for dietary fibre, neutral detergent fibre and nonstarch polysaccharides in relation to animal nutrition. Journal of Dairy Science 74: 3583-3597.

Verbič, J., Ørskov, E., Žgajnar, J., Chen, X. \& Žnidaršič-Pongrac, V. 1999. The effect of method of forage preservation on the protein degradability and microbial protein synthesis in the rumen. Animal Feed Science and Technology 82: 195-212.

Whitehead, D.C. 2000. Nutrient elements in grassland: Soilplant-animal relationship. CABI Publishing, New York, NY. 369 p.

Virkajärvi, P., Sairanen, A., Nousiainen, J.I. \& Khalili $H$. 2002. Effect of herbage allowance on pasture utilization, regrowth and milk yield of dairy cows in early, mid and late season. Animal Feed Science and Technology 97: 23-40.

Virkajärvi, P., Hakosalo, J., Sairanen, A., Halonen, R., Mononen, J., Ahola, L., Kauppinen, R., Lindeberg, H. \& Khalili, H. 2004. Comparison of the effect of night-time grazing versus silage feeding on milk production and animal welfare. In: Lüscher, A. et al. (eds.). Land use systems in grassland dominated regions: book of abstracts. 20th general meeting of the European grassland federation, Luzern, Switzerland 21-24 June 2004. Grassland Science in Europe 3.4.26. p. 125.

Virkajärvi, P. 2005. Growth rate of timothy pasture in NorthSavo. Updated August 2005. Available on the Internet: http://www.mtt.fi/tutkimus/toimipaikat/growthrate.html. 


\title{
SELOSTUS
}

\section{Osa-aikalaidun lisää lehmien maitotuotosta ja vähentää lisävalkuaisen tarvetta}

\author{
Auvo Sairanen, Hannele Khalili, Perttu Virkajärvi ja Jenni Hakosalo \\ Maa- ja elintarviketalouden tutkimuskeskus ja Kuopion yliopisto
}

Osa-aikalaiduntamisella voidaan laidun pitää käyttökelpoisena ruokintamuotona myös suurelle karjalle. Tutkimuksessa selvitettiin osa-aikalaiduntamisen vaikutusta lehmien rehunsyöntiin ja maitotuotokseen kahdessa erillisessä kokeessa vuosina 2003 ja 2005 . Molempina koevuosina laiduntamista verrattiin sisäruokintaan, jossa karja pääsi ulkotarhaan $2 \mathrm{~h}$ ajan. Ensimmäisessä kokeessa lehmät olivat laitumella yöllä (12 h laidunaika, Koe 1) ja toisessa päivällä (6 h laidunaika, Koe 2). Sisälläoloaikana kaikilla ryhmillä oli vapaa säilörehuruokinta, ja väkirehun määrä oli kaikilla lehmillä $9 \mathrm{~kg}$. Kokeessa 1 väkirehun raakavalkuainen oli $167 \mathrm{~g} / \mathrm{kg}$ kuiva-ainetta (ka). Kokeessa 2 lehmät saivat joko matalan $(135 \mathrm{~g} / \mathrm{kg}$ ka) tai korkean raakavalkuaistason väkirehua (185 g/kg $\mathrm{ka})$.

Kokeessa 1 yöaikalaidun lisäsi kokonaissyöntiä ja maitotuotosta $(3,9 \mathrm{~kg} / \mathrm{d})$. Kesäkuussa ryhmien välinen ero maitotuotoksissa oli pienin. Laidunryhmän elopaino lisääntyi kokeen aikana sisäryhmää enemmän. Kokeessa 2 päivälaidun ei lisännyt merkitsevästi keskimääräistä tuotosta kesän aikana. Maitotuotoksissa esiintyi kuukau- si × käsittely -yhdysvaikutus siten, että heinäkuussa päivälaidunryhmä lypsi $2,5 \mathrm{~kg} / \mathrm{d}$ enemmän sisällä pidettyyn ryhmään verrattuna. Väkirehun lisävalkuaisen käytöstä oli enemmän hyötyä sisäruokitulle ryhmälle kuin päivälaidunryhmälle.

Erilaiset tuotantotulokset selittyvät pääosin kokonaiskuiva-aineen syönnin eri määrillä. Laidunryhmillä karkearehuosuuden energiasisältö oli lisäksi säilörehuryhmää suurempi, joten kokonaisenergiansaanti muodostui laidunryhmillä kokonaissyönnin lisäystä suuremmaksi. Säilörehun ja laidunrehun energiasisällöt vaihtelivat molempien kokeiden aikana, ja erot laitumen hyväksi olivat suurimmillaan energia-arvoltaan matalan säilörehun aikana. Jopa heikkolaatuisinkin laidunrehu oli tuotantovaikutukseltaan vähintään hyvän säilörehun veroinen. Lisävalkuaisen heikko tuotosvaste laidunruokinnalla kuvastaa laidunrehun hyvää OIV-arvoa. Kokeen johtopäätöksenä voidaan todeta, että osa-aikalaidun lisää lehmien maitotuotosta ja vähentää lisävalkuaisen tarvetta ruokinnassa. 